ISSN 0258-7122

Bangladesh J. Agril. Res. 34(3) : 517-521, September 2009 Short Communication

\title{
FIELD SCREENING OF CHICKPEA GENOTYPES AGAINST POD BORER
}

\author{
MD. ALtAF HOSSAIN ${ }^{1}$
}

Twenty genotypes (14 lines and 6 released varieties) of chickpea were evaluated in natural infestation condition at the Regional Agricultural Research Station, Ishurdi, Pahna, Bangladesh during the rabi season of 2003-04. The parameters used for evaluating these genotypes were relative pest pressure index (RPPI), relative intensity of damage index (RPPI), relative productivity index (RPI), and yield. None of the genotypes could exhibit complete resistance to pod borer, Helicoverpa armigera (Hubner). Considering overall performance ICCV-98939, ICCV-95138, ICCV-96020, ICCV-97004, BCX-91042-3, and BCX-91040-3 rated a more tolerant to pod borer attack in comparison to check (BARI Chola-5). Of them, ICCV-95138 was the best considering resistance and yield. ICC-4918 was the most susceptible.

Chickpea (Cicer arietinum L.) also known as gram is one of the important pulse crops in Bangladesh. It is attacked by eleven species of insect pests (Rahman et al., 1982). Among these pests, the pod borer, Helicoverpa (= Heliothis) armigera (Huhner) is the most serious one in most of the chickpea growing areas of the country (Begum et al., 1992). On an average, 30 to 40 percent pods were found to be damaged by pod borer with an average of 400 $\mathrm{kg} / \mathrm{ha}$ grain loss (Rahman, 1990). In favourable condition, pod damage goes upto 90-95 percent (Shengal and Ujagir, 1990; Sachan and Katti, 1994).

Farmers mainly rely on insecticides for the management of $H$. armigera (Sachan, 1992). Insecticides are costly and indiscriminate use has induced insect resistance to the insecticides and caused environmental pollution (Phokela et al., 1990). In view of the above facts, it is needed to manage the pest in more ecofriendly approaches. That is why, efforts have been given towards exploiting the varietal resistance for pest management.

Growing a resistant variety is an ideal component of integrated pest management strategy. The development and use of less susceptible or tolerant cultivars may offer as one of the suitable components of ecofriendly pod borer management approach. Keeping this in view, 14 advanced lines and 6 released varieties were screened for determining their relative susceptibility/resistance to pod borer. Suitable tolerant chickpea genotypes also prevent pest population build up and able to compensate pest damage by producing increased number of healthy pods/plant that were taken as parameters for assessing insect- plant relationship in chickpea.

${ }^{1}$ Senior Scientific Officer (Entomology), Regional Agricultural Research Station, BARI, Ishurdi, Pabna, Bangladesh. 
The experiment was conducted at the Regional Agricultural Research Station Ishurdi, Pabna, Bangladesh during the rabi season of 2003-04. Fourteen lines collected from ICRISAT, India (ICCL 87315, ICCL 87220, ICCL 87322, ICCV 98936, ICCV 98939, ICCV 95138, ICCV 96020, ICCV 97004, ICC 4918, BCX 91040-1, BCX 91042-3, BCX 91044-3, I3CX 91043-1 and BCX 91040-3) and 6 varieties from both BARI and BINA (BINA Chola-2, BINA Chola-3, BARIChola-3, BARI Chola-4, BARI Chola-6, and BARI Chola-5 used as check) were screened against pod borer (H. armigera). The experiment was laid out in randomized complete block design (RCBD) with three replications. Varieties/ lines were considered as treatment of the experiment. The treatments were randomly allotted in each block. The seeds of respective variety/line were sown on 22 November 2003 in rows with $50 \mathrm{~cm}$ spacing. Uniform plant population was maintained by keeping $10 \mathrm{~cm}$ plant to plant distance. The unit plot size was $2 \mathrm{~m} \mathrm{x}$ 4m. Each unit plot contained 4 rows of 4 m length. NPK @ 20-40-20 kg /ha was applied at final land preparation. Normal intercultural operations were done. The crop was kept completely free from insecticidal application.

The genotypes were closely examined at weekly interval commencing from the germination to harvest. The number of pest larvae at weekly intervals and number of damaged as well as healthy pods/plant at harvest were recorded genotype-wise on ten randomly selected plants from the middle rows. For each test entry, the values of three parameters viz., relative pest pressure index (RPPI), relative intensity of damage mdcx (RIDI) and relative productivity index (RPI) were found out by using following formulae (Singh and Yadav, 1999a):

$$
\begin{aligned}
& \text { RPPI }=\frac{\text { Mean number of pest larvae/plant/day in test entry }}{\text { Mean number of pest larvae/plant/day in check }} \\
& \text { RIDI }=\frac{\text { Mean number of damaged pods/plant in test entry }}{\text { Mean number of damaged pods/plant in check }} \\
& \text { RPI }=\frac{\text { Mean number of healthy pods/plant in test entry }}{\text { Mean number of healthy pods/plant in check }}
\end{aligned}
$$

Finally, the chickpea genotypes were compared for their field reaction to the pest infestation by using the values of RPPI, RIDI, and RPI.

Plants of two middle rows, avoiding border rows of each plot comprising $4 \mathrm{~m}^{2}(\operatorname{lm} \times 4 \mathrm{~m})$ area were harvested. The pods were then threshed, grains were cleaned and dried in the bright sunshine. The grain yield was obtained from each plot and converted it into yield per hectare in $\mathrm{kg}$. 
Table 1. Field reaction of chickpea genotypes to the incidence of Helicoverpa armigera (Hubner) and yield during rabi 2003-04 at Ishurdi, Pabna, Bangladesh.

\begin{tabular}{|c|c|c|c|c|c|c|c|}
\hline Varieties/lines & $\begin{array}{c}\text { Mean no. of } \\
\text { pest larvae/ } \\
\text { plant/ day }\end{array}$ & \begin{tabular}{|c} 
Relative pest \\
pressure index \\
(RPPI)
\end{tabular} & $\begin{array}{c}\text { Mean no. of } \\
\text { damaged pods/ } \\
\text { plant }\end{array}$ & \begin{tabular}{|c} 
Relative mean \\
of damage \\
index (RIDI)
\end{tabular} & $\begin{array}{l}\text { Mean no. of } \\
\text { healthy pods/ } \\
\text { plant }\end{array}$ & $\begin{array}{c}\text { Relative } \\
\text { productivity } \\
\text { index (RPI) }\end{array}$ & Yield (kg/ha) \\
\hline ICCL-87315 & 0.038 & 0.295 & 2.80 & 0.275 & 29.37 & 0.707 & $1379 \mathrm{fg}$ \\
\hline ICCL-87220 & 0.046 & 0.357 & 8.33 & 0.819 & 32.63 & 0.786 & $888 \mathrm{j}$ \\
\hline ICCL-87322 & 0.046 & 0.357 & 9.57 & 0.941 & 30.33 & 0.730 & $1412 \mathrm{f}$ \\
\hline ICCV-98936 & 0.038 & 0.295 & 3.63 & 0.357 & 34.83 & 0.839 & $908 \mathrm{j}$ \\
\hline ICCV-98939 & 0.038 & 0.295 & 4.70 & 0.462 & 47.13 & 1.135 & $1700 \mathrm{bc}$ \\
\hline ICC V-95138 & 0.075 & 0.581 & 3.23 & 0.318 & 32.57 & 0.784 & 1866 a \\
\hline ICCV-96020 & 0.071 & 0.550 & 3.10 & 0.305 & 30.17 & 0.726 & 1683 bc \\
\hline ICCV-97004 & 0.067 & 0.519 & 7.37 & 0.725 & 34.73 & 0.836 & 1700 be \\
\hline ICC-4918 & 0.042 & 0.326 & 13.47 & 1.324 & 30.80 & 0.742 & $596 \mathrm{k}$ \\
\hline BCX-91040-1 & 0.092 & 0.713 & 6.03 & 0.593 & 32.90 & 0.792 & 1550 de \\
\hline BCX-91042-3 & 0.121 & 0.938 & 7.00 & 0.688 & 30.73 & 0.740 & $1758 \mathrm{ab}$ \\
\hline BCX-91044-3 & 0.083 & 0.643 & 6.97 & 0.685 & 34.40 & 0.828 & 1583 c-c \\
\hline BCX-91043-1 & 0.133 & 1.031 & 9.77 & 0.961 & 37.90 & 0.913 & $1675 b-d$ \\
\hline BCX-91040-3 & 0.088 & 0.682 & 5.83 & 0.573 & 38.67 & 0.931 & $1737 b$ \\
\hline BINA Chola-2 & 0.075 & 0.581 & 5.67 & 0.558 & 34.53 & 0.831 & $1271 \mathrm{gh}$ \\
\hline BINA Chola-3 & 0.129 & 1.000 & 6.73 & 0.662 & 35.17 & 0.847 & 1538 e \\
\hline BARI Chola-3 & 0.063 & 0.488 & 3.20 & 0.314 & 24.17 & 0.582 & 1192hi \\
\hline BARI Chola-4 & 0.071 & 0.550 & 9.97 & 0.980 & 24.03 & 0.579 & $1142 \mathrm{i}$ \\
\hline BARI Chola-6 & 0.033 & 0.256 & 10.87 & 1.070 & 37.77 & 0.910 & $1134 \mathrm{i}$ \\
\hline BARI Chola-5 (check) & 0.129 & 1.000 & 10.17 & 1.000 & 41.53 & 1.000 & 1654b-e \\
\hline
\end{tabular}

In a column, treatment means having the same letter(s) are not significantly different by DMRT at 5\% level. 
The experimental data were analyzed by MSTAT-C software. Mean comparisons for treatment parameters were made using Duncan's Multiple Range Test (Steel and Torrie, 1960) at 5\% level of significance.

Out of 20 genotypes (Table 1), BCX-91043-1, BINA Chola-3, BARI Chola-5 (check), and BCX-91042-3 carried maximum pest load (0.121 to 0.133 larvae/plant/day) and ICCL 87315, ICCV-98936, and ICCV-98939 carried minimum pest load (0.038 larvae/plant/day). On the basis of RPPI values, almost all the genotypes carried less pest pressure than the check (BARI Chola-5) except BCX-91043-1. In respect of the intensity of damaged pods; genotypes recorded wide variation (2.80 to 13.47 damaged pods/plant). The mean number of damaged pods/plant being as low as 2.80 and as high as 13.47 in case of ICCL87315 and ICC-4918, respectively, as against 10.17 in the check. The RIDI value revealed that ICCL-87315 is the most tolerant line (RIDI $=0.275$ ), almost closer to ICCV-95138 and ICCV-96020. The most susceptible line was JCC-4918 (RIDl 1.324). The highest RPI value (1.135) was recorded in ICCV-98939 but produced lower yield $(1700 \mathrm{~kg} / \mathrm{ha})$ than other varieties. This might be due to smallest seed size of ICC V-98939. The RPI value of ICCV-95138 was 0.784 but produced the highest yield (1866 kg ha). This might be due to the largest seed size of ICCV-95 138. All the genotypes recorded the lower RPI value than the check except ICCV-98939. The higher value of RPI was not always produced higher yield. This was because of podding potentiality, pod size, seed size, and seed weight which varied widely among the genotypes.

When considering three parameters (RPPI, RIDI, RPI) together, the relative position of the genotypes with respect to check did not follow any definite trend. These findings are agreed with the findings of Singh and Yadav, 1999b. Considering overall performance, ICCV-98939, ICCV-95138, ICCV-96020, ICCV-97004, BCX-91042-3, and BCX-91040- 3 rated as less susceptible or more tolerant to pest attack in comparison to check. Of them, ICCV-95138 is the best.

\section{References}

Begum, N., M. Hussain and S.I. Chowdhury. 1992. Effect of sowing date and plant density to pod borer incidence and grain yield of chickpea in Bangladesh. Intl. Chickpea Newslet. 27: 19-21.

Phokela, A., S. Dhingra, S.N. Sinha and K.N. Mehrotra. 1990. Pyrethroid resistance in Heliothis armigera Hb. III Development of resistance in field. Pestic. Re.s .J. 2( 1): 28-30.

Rahman, M.M. 1990. Infestation and yield loss in chickpea due to pod borer in Bangladesh. Bangladesh J. Agril. Res. 15(2): 16-23. 
Rahman, M.M., M.A. Mannan and M.A. Islam. 1982. Pest survey of major summer and winter pulses in Bangladesh. In: Proceedings of the National Workshop on Pulses. August 18-19, 1981. Edited by A.K. Kaul. Published by Director, Bangladesh Agricultural Research Institute, Joydebpur, Dhaka. pp 265-273.

Sachan, J.N. 1992. Pest status of Helicoverpa armigera in pulses and strategies for its management. pp. 7-23 in Helicoverpa management: Current status and future strategies, Proceedings of the first National Workshop (Sachan, J.N., ed.). Kanptir, Uttar Pradesh, India: Directorate of Pulses Research.

Sachan, J.N. and G. Katti. 1994. Integrated Pest Management. Proceeding of International Symposium on Pulses Research, April 2-6, 1994 IARI, New Delhi, India. pp. 23-30.

Shengal, V.K. and R. Ujagir. 1990. Effect of synthetic pyrethroids, neem extracts and other insecticides for the control of pod damage by Helicoverpa armigera on chickpea and pod damage-yield relationship at Patancheru in Northern India. Crop Protection 9: 29-32.

Singh, B. and R.P. Yadav. 1999a. Location of sources of resistance amongst chickpea (Cicer arietinum L.) genotypes against gram pod borer (Heliothis armigera Hub.) under normal sown conditions by using new parameters. J. Ent. Res. 23(1): 19-26.

Singh, B. and R.P. Yadav. 1999b. Field screening of chickpea (Cicer arietinum L.) genotypes against gram pod borer (Heliothis armigera Hub.) under late sown conditions. J. Ent. Res. 23(2): 133-140.

Steel, R.G.D. and J.H. Torrie. 1960. Principles and Procedures of Statistics, pp. 107-109. McGraw-Hill Book. Co. Inc., New York. 